\title{
The role of magnetic resonance diffusion tensor imaging in differentiation of benign from malignant focal renal lesions
}

\author{
Fokal renal lezyonlarının benign ve malign ayırımında manyetik rezonans difüzyon tensör \\ görüntülemenin rolü \\ Sukru Mehmet ERTURK, Fikriye YILMAZ UZUNOGLU, Abdullah SOYDAN MAHMUTOGLU, Ozge YAPICI \\ UGURLAR, Guzide OZDIL, Alper OZEL, Onder KIRDAR, Muzaffer BASAK
}

\begin{abstract}
Objectives: To determine the diagnostic performance of apparent diffusion coefficient (ADC) and fractional anisotropy (Fa) measurements in differentiation of malignant from benign focal renal lesions.

Material and Methods: Twenty-one patients ( 9 women and 12 men ; mean age 54,1 years) with 25 focal renal lesions diagnosed by different imaging modalities such as computed tomography (CT) and ultrasound (US) and examined with magnetic resonance diffusion tensor imaging (DTI) were included in the study. There were 6 solid renal cell carcinomas (RCC), 1 cystic RCC, 1 angiomyolipoma (AML) and 17 cystic lesions ( 16 Bosniak type I cysts, 1 Bosniak type II cyst). ADC and Fa measurements were performed by two radiologists, in consensus. The differences in $\mathrm{ADC}$ and $\mathrm{Fa}$ values of malignant and benign renal lesions were compared using ANOVA and Tukey tests. A ROC analysis was applied; sensitivities and specificities were calculated.

Results: The mean ADC and Fa values of malignant lesions were $1.29 \pm 0.4 \mathrm{~mm} 2 / \mathrm{sec}$ and $0.34 \pm 0.1$, respectively. The mean $\mathrm{ADC}$ and $\mathrm{Fa}$ values of benign lesions were $2.6 \pm 0.7 \mathrm{~mm} 2 / \mathrm{sec}$ and $0.19 \pm 0.12$, respectively. The differences were significant $(P<0.05)$. The Az values for discriminating malignant lesions from benign ones for ADC and Fa value were 0.95 and 0.83 , respectively.
\end{abstract}

Şukru Mehmet Erturk, Alper Ozel, Muzaffer Basak

Radiology Department, Sisli Hamidiye Etfal Training and Research Hospital, Istanbul, Turkey

Fikriye Yilmaz Uzunoglu

Radiology Clinic, Carsamba State Hospital, Ordu, Turkey

Abdullah Soydan Mahmutoglu (四)

Radiology Department, Istanbul Training and Research Hospital, Istanbul, Turkey

e-mail:asmahmutoglu@yahoo.com

Ozge Yapıcı Ugurlar

Radiology Department, Trakya University Medical Faculty, Edirne, Turkey

Guzide Ozdil

Radiology Department, Bilim University Medical Faculty, Istanbul, Turkey

Onder Kirdar

Radiology Clinic, Lara Anadolu Hospital, Antalya, Turkey

Submitted / Gönderilme: 19.01.2017

Accepted/Kabul: 17.03.2017
The sensitivity-specificity of ADC and Fa were $100 \%-83.3 \%$, and $100 \%-77.8 \%$, respectively.

Conclusion: There are statistically significant differences between ADC and Fa values of malignant and benign focal renal lesions. Malignant renal lesions have low ADCs and high $\mathrm{Fa}$ values, whereas benign renal lesions have high ADCs and low $\mathrm{Fa}$ values.

Keywords: Magnetic resonance, Diffusion tensor, Renal lesion

\section{Öz}

Amaç: Fokal böbrek lezyonlarının benign, malign ayırımında görünüşteki difüzyon katsayısı (apparent diffusion coefficient - ADC) ve fraksiyonel anizotropi (Fa) ölçümlerinin diagnostik performanslarının belirlenmesi.

Gereç ve Yöntem: Çalışmamıza, bilgisayarlı tomografi (BT) ve ultrason (US) gibi değişik görüntüleme modaliteleri ile tanı konulan ve manyetik rezonans diffüzyon tensör görüntülemesi (DTI) yapılmış 21 hastada ( 9 kadın and 12 erkek ; ortalama yaş 54,1 ), 25 fokal renal lezyon dahil edildi. Lezyonlar 6 solid renal hücreli karsinom (RCC), 1 kistik RCC, 1 anjiomyolipom (AML) ve 17 kistik lezyondan ( 16 Bosniak tip I kist, 1 Bosniak tip II kist) oluşmaktaydı. ADC ve Fa ölçümleri iki radyolog tarafından, konsensusa varılarak yapıldı. Malign ve benign lezyonlara ait ADC ve Fa değerleri ANOVA ve Tukey testleri kullanılarak karşılaştırıldı. ROC analizi kullanıldı; sensitivite ve spesifite hesapland1.

Bulgular: Malign lezyonların ortalama ADC ve Fa değerleri sırasıyla $1.29 \pm 0.4 \mathrm{~mm} 2 / \mathrm{sn}$ ve $0.34 \pm 0.1$ ölçüldü. Benign lezyonların ortalama $\mathrm{ADC}$ ve $\mathrm{Fa}$ değerleri sirasıyla $2.6 \pm 0.7 \mathrm{~mm} 2 / \mathrm{sn}$ ve $0.19 \pm 0.12$ ölçüldü. Aralarındaki fark istatistiksel olarak anlamlı idi $(P<0.05)$. Malign lezyonları, benign lezyonlardan ayırmada ADC ve Fa ölçümlerinin, Az değerleri sırasıyla 0.95 ve 0.83 bulundu. $\mathrm{ADC}$ ve $\mathrm{Fa}$ ölçümlerinin sensitivite ve spesifite değerleri sırasıyla $100 \%-83.3 \%$ ve $100 \%-77.8 \%$ bulundu.

Sonuç: Malign ve benign fokal renal lezyonların ADC ve Fa ölçümleri değerleri arasında istatistiksel anlamlı farklar mevcuttur. Malign renal lezyonlarda düşük ADC ve yüksek Fa değerleri izlenirken, benign renal lezyonlarda yüksek $\mathrm{ADC}$ ve düşük $\mathrm{Fa}$ değerleri izlenir.

Anahtar kelimeler: Manyetik rezonans, Difüzyon tensör, Renal lezyon 


\section{Introduction}

Diffusion-weighted magnetic resonance imaging (DWMRI) is a noninvasive technique that visualizes molecular diffusion by measuring the Brownian motion of water molecules in the tissues. This mobility shows the integrity of cell membrans and the cellularity of the underlying tissue [1]. The water within the intracellular and extracellular spaces have changes in the micro diffusion which have an effect on DW-MRI outcomes. Apparent diffusion coefficient (ADC) is the indicator of movement of water molecules in a tissue [2]. Generally, in a malignant lesion the cells are densely packed and due to existence of more organelles, membranes and fibers within the malignant cells, diffusion is restricted and $\mathrm{ADC}$ values are lower [3].

Because diffusion is a multidimensional process the use of DWI alone may result in a loss of important data within highly organized (i.e., anisotropic) tissues. Using additional gradients magnetic resonance diffusion tensor imaging (DTI) can evaluate the anisotropic features of tissues and allow the analysis of diffusion in multiple dimensions, thus provide more detailed data regarding the diffusion of water in various tissues [4-6]. Fractional anisotropy (Fa) shows the fraction of anisotropic diffusion to total diffusion. Furthermore, in a study, the authors showed that Fa has a good and strong correlation with cell density [7].

Our hypothesis is thus that the diffusion in malignant lesions should be more restricted and more anisotropic when compared with benign renal lesions because of higher cell density in malignant ones. The purpose of this preliminary study is to test this hypothesis.

\section{Materials and Methods}

\section{Patients}

Institutional approval for this retrospective study and written informed consents from all patients had been obtained. During six months 21 patients ( 9 women and 12 men ; mean age 54,1 years) with renal lesions diagnosed by different imaging modalities such as computed tomography (CT) and ultrasound (US) and examined with DTI were included in this study.

$\mathrm{ADC}$ and $\mathrm{Fa}$ values of 25 lesions of these 21 patients were evaluated. There were 6 solid renal cell carcinomas (RCC), 1 cystic RCC, 1 angiomyolipoma (AML) and 17 cystic lesions ( 16 Bosniak type I cysts, 1 Bosniak type II cyst). The diagnosis of RCC's were proven by means of biopsy. Angiomyolipoma was diagnosed according to typical MRI appearance. Cysts enrolled in the study were diagnosed according to their typical US and MRI findings. All benign cysts were followed up for at least 12 months.

\section{MR Imaging}

A 1.5T Scanner (Signa Excite HD; Healthcare, Milwaukee, WI, USA ) was used for all MR examinations. Axial breathhold, single-shot gradient echo planar DTI covering both kidneys were acquired using the following parameters: Matrix: 256x160, Acquisition time: 1:25 (min:sec), TE: $89.4 \mathrm{msec}$, TR: $6125.0 \mathrm{msec}$, Bandwith: $31.25 \mathrm{kHz}$, number of excitations: 4.0, field of view: 48, Slide thickness: 8.0 $\mathrm{mm}$, Spacing: $1.0 \mathrm{~mm}$, b-value: $1000 \mathrm{sec} / \mathrm{mm} 2$, number of diffusion directions: 6 Spectro Spatial RF pulse was used to reduce chemical shift artifacts.

\section{Image Analysis}

All images were reviewed by two radiologists (study coordinators), who were aware of the final diagnoses of the lesions, on postprocessing workstations and lesions were determined to be measured. When a patient had different types of lesions, all of them were included, otherwise the largest was chosen.

To analyse $\mathrm{ADC}$ and Fa values, two readers, who were blinded to the lesions, established regions of interest in each lesion on ADC and Fa maps, in consensus. All regions of interest were placed within the confines of the lesions; for heterogeneous lesions, regions of interest included the entire lesion.

\section{Statistical Evaluation}

The differences in ADC and $\mathrm{Fa}$ values of RCC's, angiomyolipoma and cysts were evaluated using ANOVA and post-hoc Tukey test. ROC analysis was applied to evaluate the use of ADC and Fa values in distinguishing malignant lesions from benign ones. The areas under the curve were calculated. Cut-off values for ADCs and Fa values were determined for discriminating malignant lesions from benign ones. Sensitivities and specificities with $95 \%$ confidence intervals (CI) were calculated accordingly. 

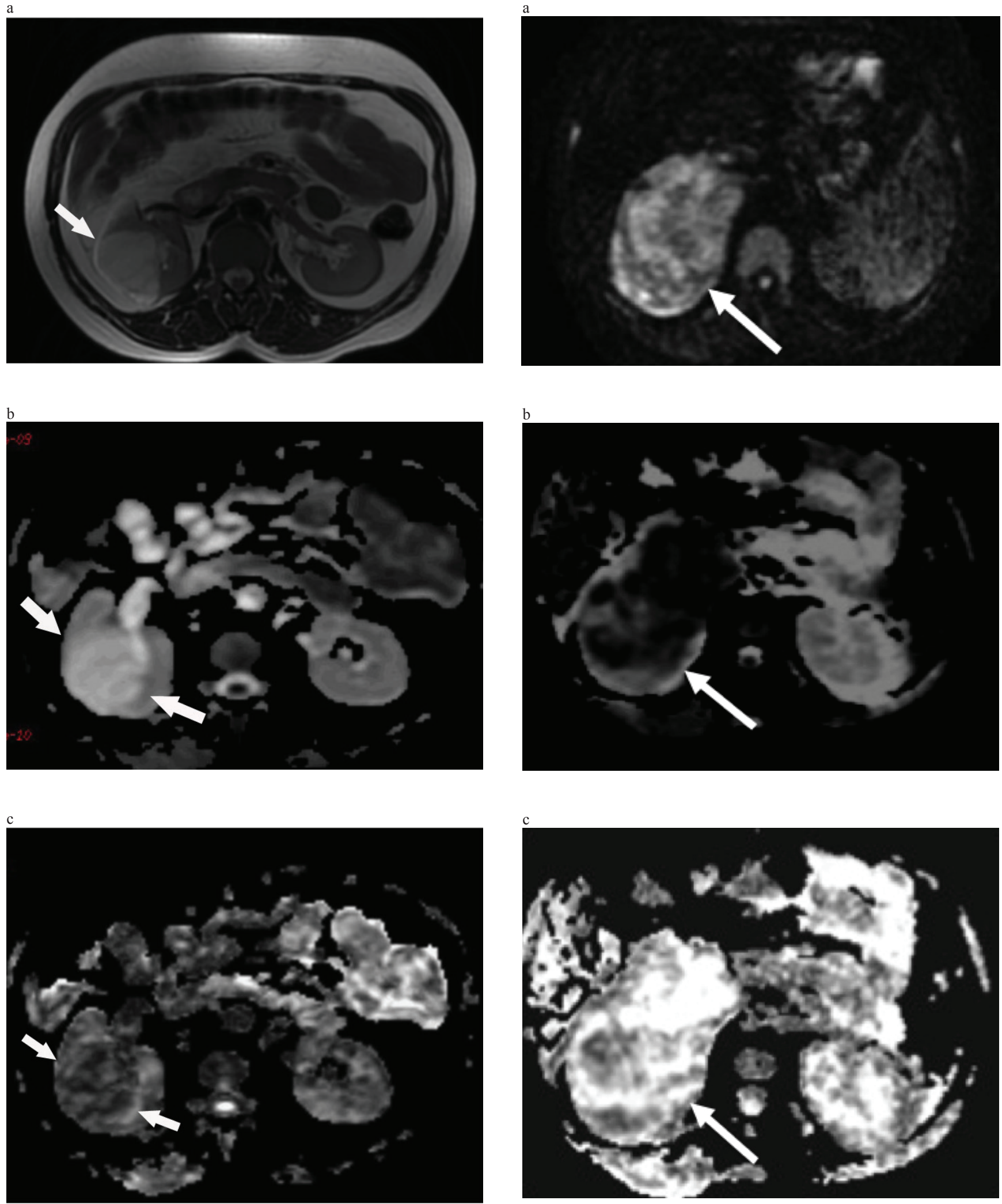

Figure 1: A renal cyst (white arrow) in the right kidney appears hyperintense on T2-weighted image (figure 1a). The cyst has an ADC value of $2.72 \times 10-3 \mathrm{~mm}^{2} / \mathrm{s}$ and an $\mathrm{Fa}$ value of 0.16 . Figure parts $1 \mathrm{~b}$ and $1 \mathrm{c}$ are ADC and Fa maps, respectively.

Figure 2: A cystic RCC (white arrow) in the right kidney appears hyperintense on diffusion-weighted axial image (figure 2a). After intravenous injection of gadolinium, the lesion shows weak enhancement because of its cystic nature (figure $2 \mathrm{~b}$ ). The RCC had an $\mathrm{ADC}$ value of $1.07 \times 10^{-3} \mathrm{~mm}^{2} / \mathrm{s}$ and an $\mathrm{Fa}$ value of 0.31 . Figure parts $2 \mathrm{c}$ and $2 \mathrm{~d}$ are ADC and Fa maps, respectively. 


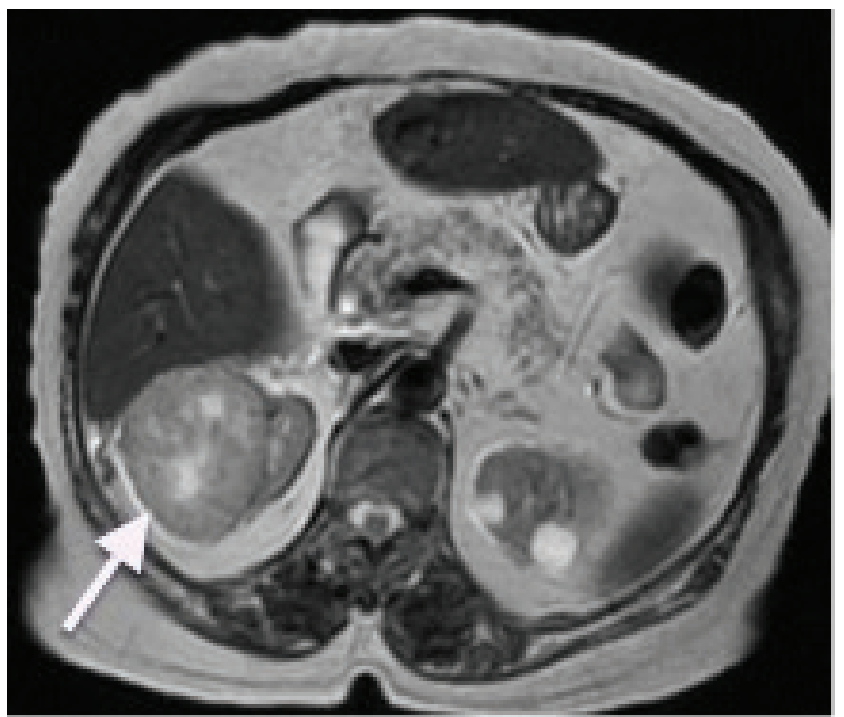

b
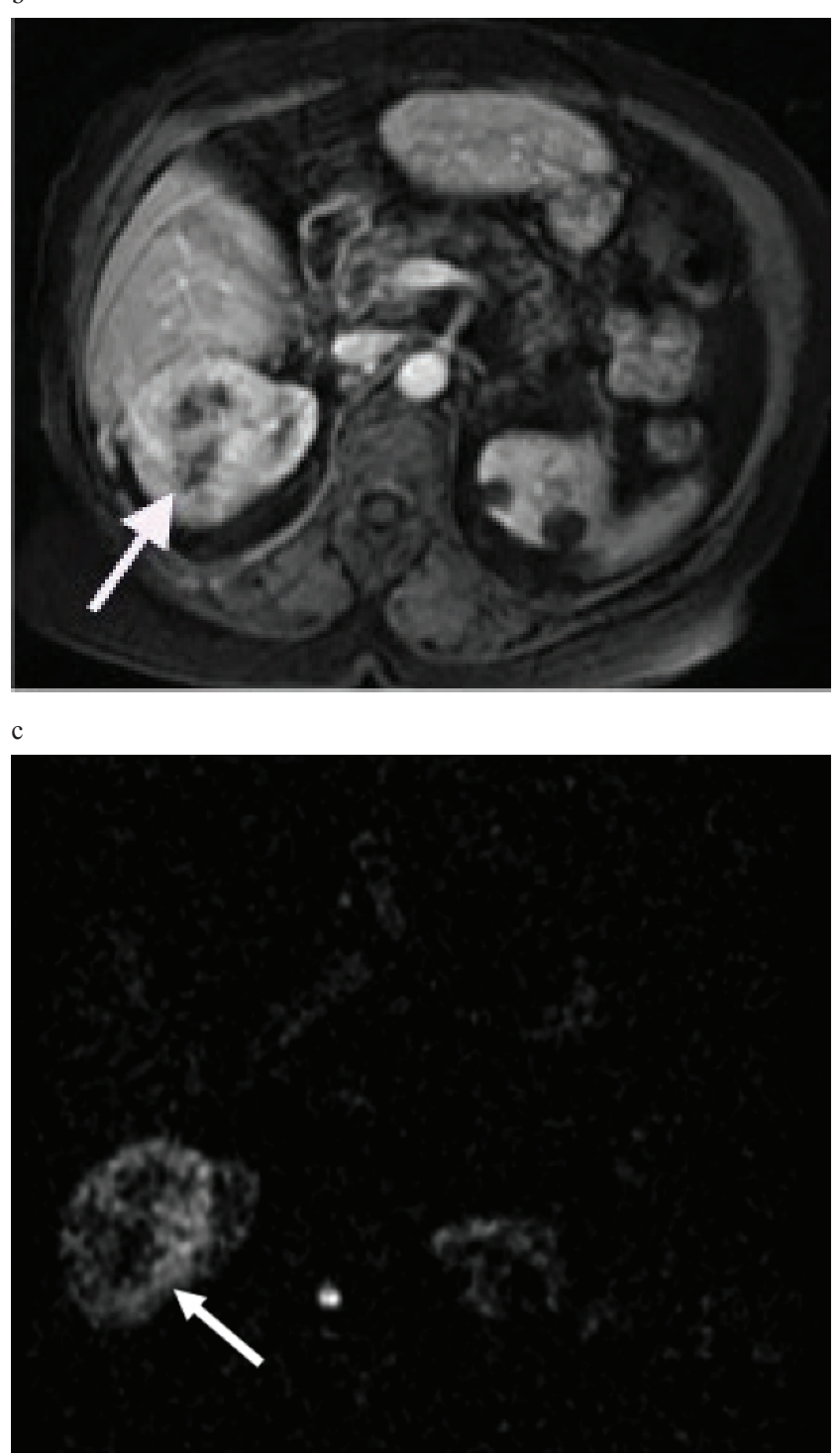

d

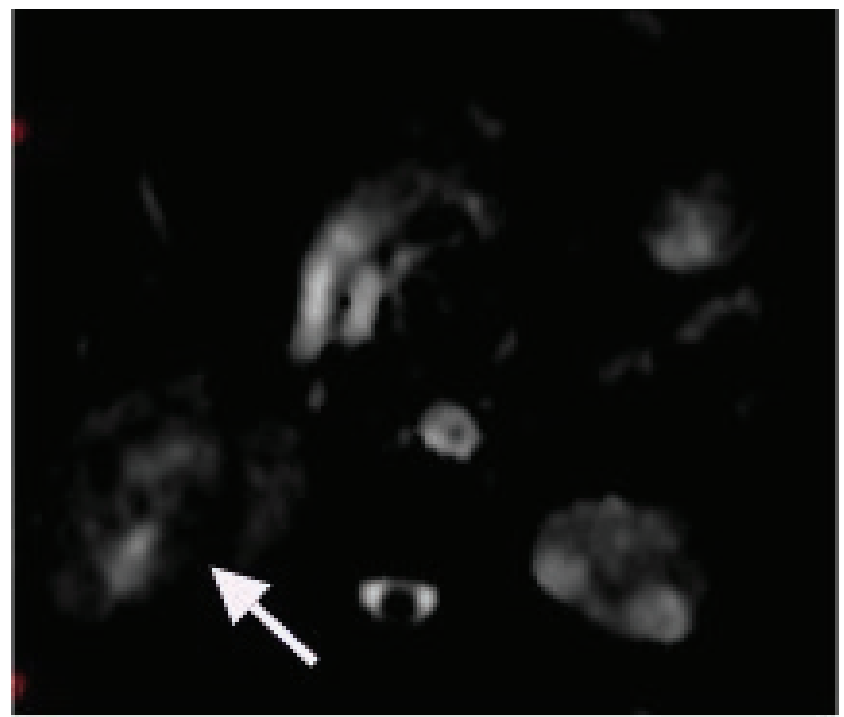

$\mathrm{e}$

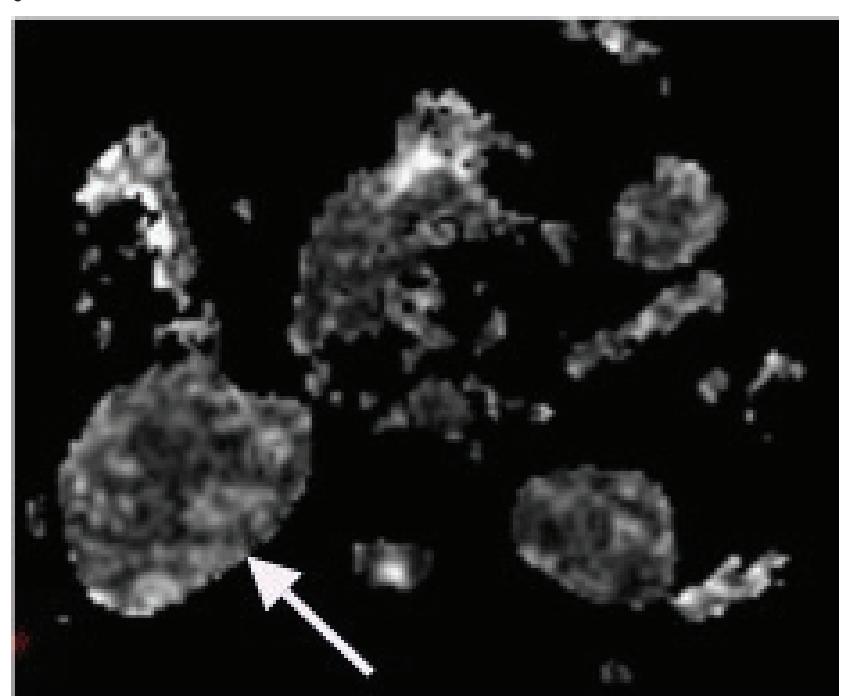

Figure 3: A RCC (white arrow) in the right kidney appears heterogeneously isointense when compared with renal parenchyma with internal hyperintense areas of cystic degeneration on T2weighted image; two simple cysts in the left kidney appear hyperintense (figure 3a). After gadolinium administration, the RCC shows strong enhancement, the cysts appear hypointense (figure $3 \mathrm{~b}$ ). The RCC shows diffusion restriction and appears hyperintense on diffusion weighted MR image; the cysts appear hypointense (figure $3 \mathrm{c}$ ); figures $3 \mathrm{~d}$ and $3 \mathrm{e}$ are $\mathrm{ADC}$ and $\mathrm{Fa}$ maps, respectively. The RCC had an ADC value of $1.67 \times 10^{-3} \mathrm{~mm}^{2} / \mathrm{s}$ and an Fa value of 0.29 , with necrotic areas of higher ADC and lower Fa values. The larger simple cyst had an ADC value of $2.61 \times 10^{-3}$ $\mathrm{mm}^{2} / \mathrm{s}$ and 0.15 , respectively. 
a

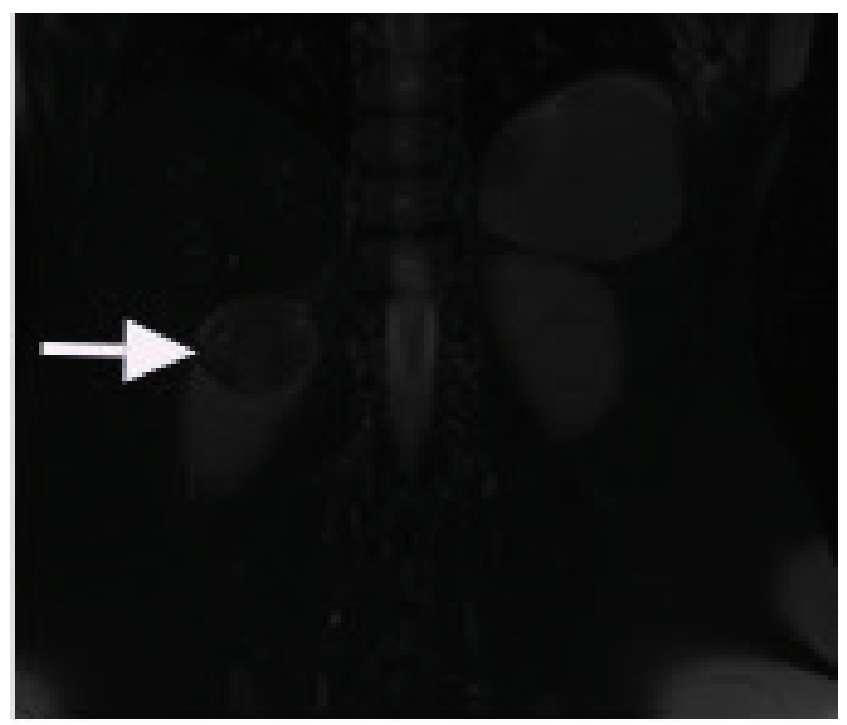

b

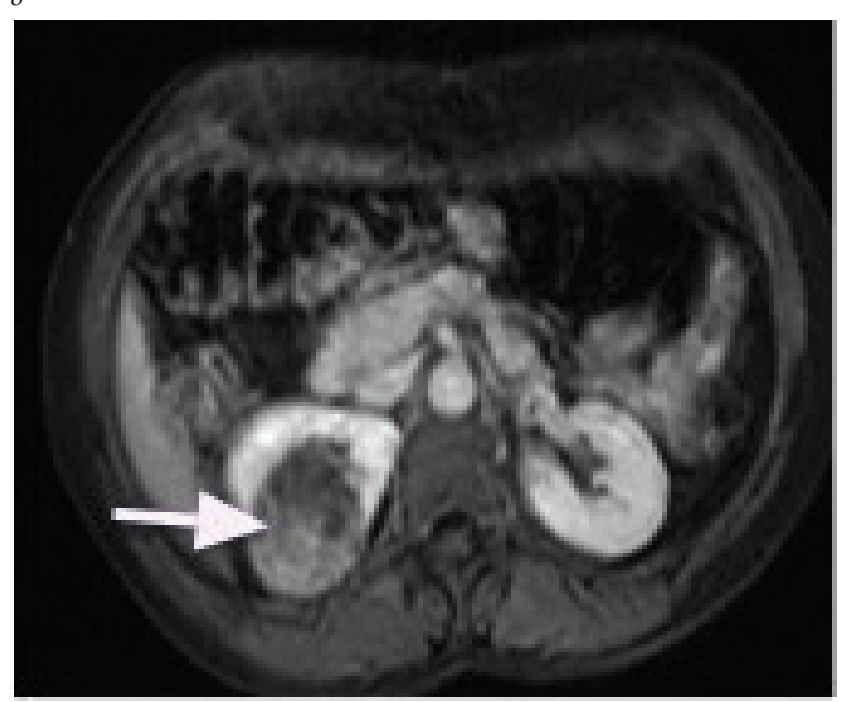

c

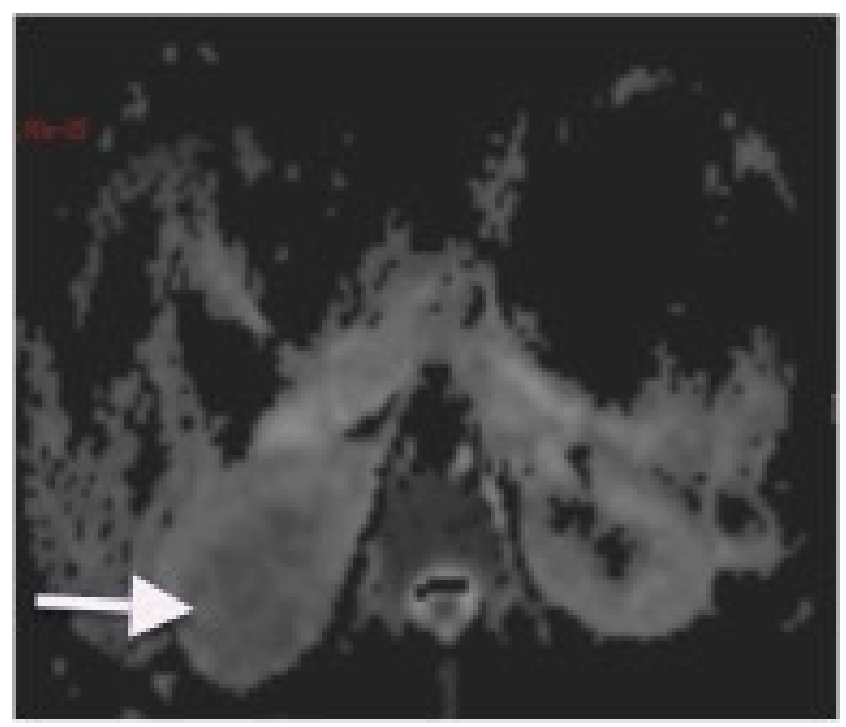

d

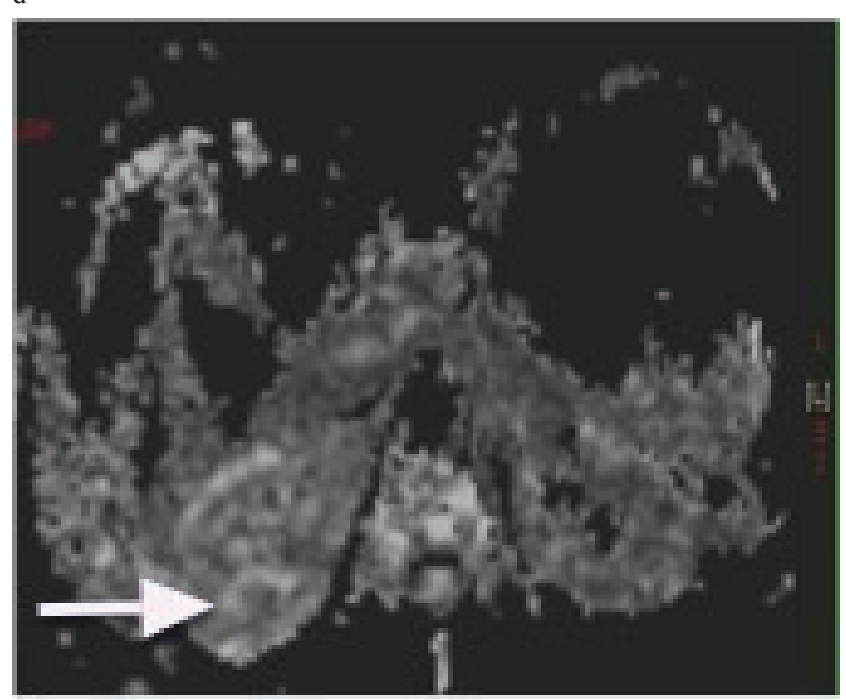

Figure 4: An angiomyolipoma (white arrow) in the right kidney appears as a fat containing lesion on coronal fatsupressed T2-weighted images (figure 4a). Lesion shows enhancement after gadolinium administration (figure $4 \mathrm{~b}$ ). The angiomyolipoma had an ADC value of $1.38 \times 10^{-3} \mathrm{~mm}^{2} / \mathrm{s}$ and an Fa value of 0.34 . Figures $4 \mathrm{c}$ and $4 \mathrm{~d}$ are ADC and Fa maps, respectively.

\section{Results}

The mean ADC values of RCCs and benign renal lesions were $1.29 \pm 0.4 \times 10^{-3} \mathrm{~mm}^{2} / \mathrm{s}, 2.6 \pm 0.7 \times 10^{-3} \mathrm{~mm}^{2} / \mathrm{s}$, respectively. All differences were significant $(P<0.05)$. The mean $\mathrm{Fa}$ values of malignant and benign lesions were $0.34 \pm 0.1$ and $0.19 \pm 0.12$, respectively. The differences in Fa values were statistically significant $(P<0.05)$. Figures $1,2,3$ and 4 are representative cases.
In distinguishing between malignant and benign lesions, ADC value had an area under the curve of 0.95. Using $1.87 \times 10^{-3} \mathrm{~mm}^{2} / \mathrm{s}$ as the cut-off value the sensitivity was $100 \%(7 / 7 ; 95 \% \mathrm{CI}=64.6-100 \%)$ and the specificity was $83.3 \%(15 / 18 ; 95 \% \mathrm{CI}=60.8-94.2 \%)$. In distinguishing malignant lesions from benign ones, Fa value had an area under the curve of 0.83 . Using 0.25 as the cut-off value the sensitivity was $100 \%(7 / 7 ; 95 \% \mathrm{CI}=64.6-100 \%)$ and the specificity was $77.8 \%(14 / 18 ; 95 \% \mathrm{CI}=54.8-91.0 \%)$. 


\section{Discussion}

The ADC values depend largely on the presence of barriers to diffusion within the macromolecules and cell organels. Restriction to the molecular diffusion of water can be related to the density of tissues. With the increasing density according to the compartment within different cellular structures and macromolecules, ADC values changes, thus helps us to differentiate the types of tissues. Incresed cell density causes an increase in the anisotropy, as well [7]. Since it has been already shown that the cells in malignant lesions are densely packed [3], the diffusion in malignant lesions should be more restricted and more anisotropic when compared to benign lesions resulting in outcomes as lower $\mathrm{ADC}$ values and higher $\mathrm{Fa}$ values for malignant lesions.

In the literature there are studies that investigate the accuracy of DWI to assess parenchymal structure of kidneys, characterization of renal masses and cystic renal lesions [8-10]. Kim et al., found the lowest ADC values in angiomyolipoma and renal cell carcinoma in their study [11]. Notohamiprodjo et al., used DTI in patients with renal pathologies and in healthy volunteers. The results of their study showed that solid tumors had significantly higher Fa values compared to simple cysts, but a wide range of Fa values were detected for renal cell carcinoma [12]. In a study by Taouli et al., RCCs had significantly lower mean ADC values compared to benign renal lesions at DWI. The mean ADC was $1.41 \pm 0.61 \times 10^{-3} \mathrm{~mm}^{2} / \mathrm{s}$ for RCCs and $2.23 \pm 0.87 \times 10^{-3} \mathrm{~mm}^{2} / \mathrm{s}$ for all benign lesions in their study [13]. In our study, the mean ADC values we obtained for RCCs and benign renal lesions are in concordance with the literature. And as expected, due to their higher cell density, RCCs had higher Fa values when compared with the benign lesions.

This preliminary study has some limitations. First, the patient population was small. Nevertheless, we were still able to find statisticaly significant differences between $\mathrm{ADC}$ and $\mathrm{Fa}$ values of malignant and benign focal renal lesions. Malignant lesions had low ADCs and high Fa values, whereas benign lesions had high ADCs and low Fa values. Second we were not able to include different type of solid renal lesions other than one angiomyolipoma. As we mentioned earlier, our aim in this preliminary study, was to evaluate the feasibility of diffusion tensor imaging. To reach robust conclusions, studies with larger patient populations, and a variety of renal lesions are definitely needed.
Conflict of Interest: The authors declare that they have no conflict of interest.

\section{References}

1. Le Bihan D, Breton E, Lallemand D, Aubin ML, Vignaud J, Laval-Jeantet M. Separation of diffusion and perfusion in intravoxel incoherent motion MR imaging. Radiology 1988;168:497-505. doi: 10.1148/radiology.168.2.3393671

2. Bonekamp S, Torbenson MS, Kamel IR. Diffusion-weighted magnetic resonance imaging for the staging of liver fibrosis. J Clin Gastroenterol 2011;45:885-92. doi: 10.1097/ MCG.0b013e318223bd2c

3. Sugita R, Ito K, Fujita N, Takahashi S. Diffusion-weighted MRI in abdominal oncology: Clinical applications. World J Gastroenterol 2010;16:832-6.

4. Gurses B, Kabakci N, Kovanlikaya A, et al. Diffusion tensor imaging of the normal prostate at 3 Tesla. Eur Radiol 2008; 18:716-21. doi:10.1007/s00330-007-0795-7

5. Le Bihan D, Mangin JF, Poupon C, et al.Diffusion tensor imaging: concepts and applications. J Magn Reson Imaging 2001;13:534-46.

6. Gurses B, Tasdelen N, Yencilek F, et al.Diagnostic utility of DTI in prostate cancer. Eur J Radiol 2011; 79:172-6. doi: 10.1016/j.ejrad.2010.01.009

7. Kinoshita M, Hashimoto N, Goto $\mathrm{T}$, et al. Fractional anisotropy and tumor cell density of the tumor core show positive correlation in diffusion tensor magnetic resonance imaging of malignant brain tumors. Neuroimage 2008;43:2935. doi: 10.1016/j.neuroimage.2008.06.041

8. Thoeny HC, De Keyzer F, Oyen RH, Peeters RR. Diffusionweighted MR imaging of kidneys in healthy volunteers and patients with parenchymal diseases: initial experience. Radiology. 2005;235:911-7. doi: 10.1148/radiol.2353040554

9. Cova M, Squillaci E, Stacul F, et al. Diffusion-weighted MRI in the evaluation of renal lesions: preliminary results. Br J Radiol 2004;77:851-7. doi: 10.1259/bjr/26525081

10. Inci E, Hocaoglu E, Aydin S, Cimilli T. Diffusion-weighted magnetic resonance imaging in evaluation of primary solid and cystic renal masses using the Bosniak classification. Eur J Radiol 2012 ;81:815-20. doi : 10.1016/j.ejrad.2011.02.024

11. Kim S, Jain M, Harris AB, Lee VS, Babb JS, Sigmund EE, et al. T1 hyperintense renal lesions: characterization with diffusion-weighted MR imaging versus contrast-enhanced MR imaging. Radiology 2009; 251:796-807. doi: 10.1148/ radiol.2513080724

12. Notohamiprodjo M, Glaser C, Herrmann KA, et al. Diffusion tensor imaging of the kidney with parallel imaging: initial clinical experience. Invest Radiol 2008; 43:677-85. doi: 10.1097/RLI.0b013e31817d14e6

13. Taouli B, Thakur RK, Mannelli L, et al. Renal lesions: characterization with diffusion-weighted imaging versus contrast-enhanced MR imaging. Radiology. 2009;251:398407. doi: 10.1148/radiol.2512080880 